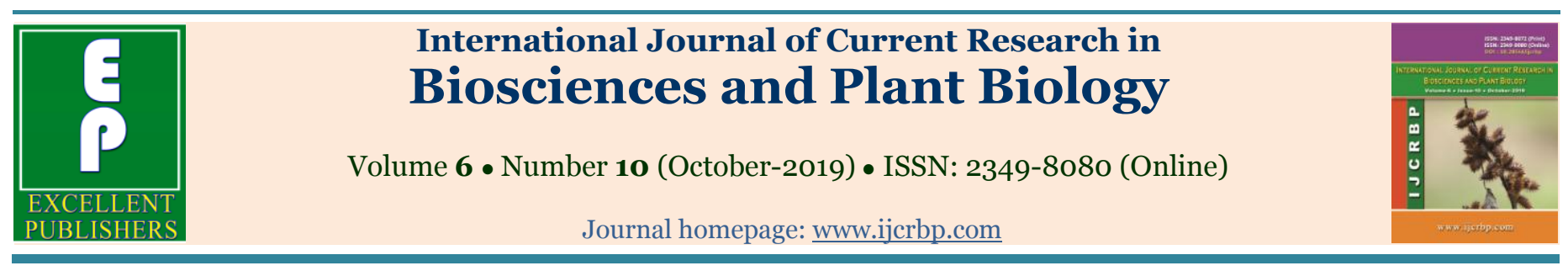

\title{
White blood cell profile during third trimester of pregnancy in Sokoto, Nigeria
}

\section{Adamu Jibril Bamaiyi* and Kabiru Abdullahi Ladan}

\author{
Department of Physiology, Faculty of Basic Medical Sciences, College of Health Sciences, \\ Usmanu Danfodiyo University, Sokoto, Nigeria \\ *Corresponding author; e-mail: adamu.jibril@udusok.edu.ng
}

\begin{tabular}{|c|c|}
\hline Article Info & \multirow{4}{*}{ 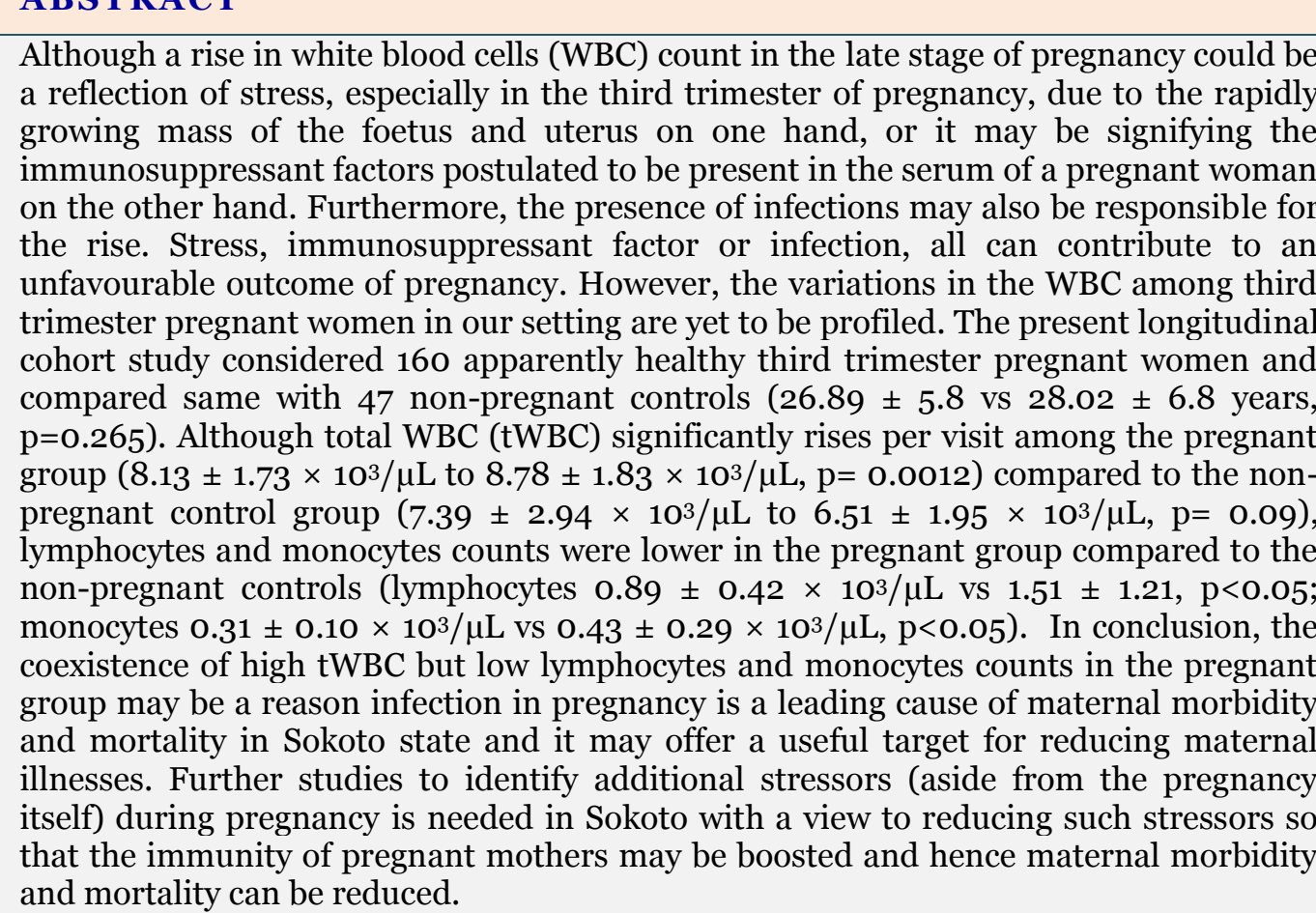 } \\
\hline $\begin{array}{l}\text { Date of Publication: } \\
\text { o6 October } 2019\end{array}$ & \\
\hline Keywords & \\
\hline $\begin{array}{l}\text { Immunosuppressant } \\
\text { factor } \\
\text { Morbidity } \\
\text { Mortality } \\
\text { Pregnancy } \\
\text { Third trimester } \\
\text { White blood cell }\end{array}$ & \\
\hline
\end{tabular}

\section{Introduction}

Pregnancy is a thing of joy, especially when properly managed. A proper management of it therefore entails being familiar with the changes including haematological, which comes with pregnancy to guarantee a favourable outcome (Kaur et al., 2014). Third trimester of pregnancy is associated with some form of stress including those arising from the rapidly growing foetus and uterus (Ciliberto and Gertie, 1998, Kaur et al., 2014). This stress, together with some other factors of 
pregnancy require the body immune systems adjusting to meet up the challenges (Mor and Cardenas, 2010) and may be reflected in WBC profile seen as leucocytosis (Pughikumo et al., 2015, Gebreweld et al., 2018, Wang et al., 2016, Malikarjun et al., 2018; Duru et al., 2016). This however, doesn't exclude the presence of some other reasons that may occasion leucocytosis in pregnancy such as infection (Ramsay, 2010; Serrano et al., 2011) or gestational diabetes mellitus (Pattanathaiyanon et al., 2014). Indeed, a tWBC value above normal levels alone during pregnancy will necessitate some investigations to rule out the presence of infection (Ramsay, 2010). In this regard, infection is a major cause of maternal mortality rate in Sokoto, Northwest Nigeria (Audu and Ekele, 2002; FIGO, 2013). Moreover, earlier studies all over the globe on pregnancy have profiled WBC counts and its differentials and the factors that may be responsible for the variations were highlighted (Ahmed et al., 2018, Akingbola et al., 2006, Pughikumo et al., 2015). However, disparate and yet normal reports were presented (Akingbola et al., 2006, Ahmed et al., 2018, Dapper et al., 2006). Importantly, the study by Pughikumo and colleagues (2015) reported monocytosis in the third trimester of pregnancy and lower lymphocytes counts were also reported elsewhere (Bamaiyi et al., 2015, Ramsay, 2010). Nevertheless, Obeagu et al. (2014) reported depressed monocyte counts in late pregnancy. Moreover, the work of Dapper and co-workers (2006) in Port Harcourt, South-South Nigeria reported lower Leucocytes count in the third trimester of pregnancy compared with earlier periods of pregnancy. However, many others (Ahmed et al., 2018; Akingbola et al., 2006; Akinlaja, 2016; Pughikumo et al., 2015; Ciliberto and Gertie, 1998) reported contrary findings. Further, impacts of ethnicity, environmental and genetic factors as possible mediators of variations in WBC counts have been controversial (Ichipi-Ifukor et al., 2013; Shen et al., 2010; Dapper and Didia, 2006). Indeed, maternal death from pregnancy related causes may be determined by many factors, and the factors that predominate in causing these deaths depend on the regions under consideration. In this regard, Sokoto state, North-west Nigeria has one of the highest maternal mortality ratios, reported to be 1,151/100,000 (Audu and Ekele, 2002). In this regard, a more recent report revealed that maternal deaths in Sokoto maybe higher than the Nigerian national average of 560/100,000 (Mojekwu and Ibekwe, 2012) and infection control during pregnancy has been identified as a modality for reducing maternal deaths in Sokoto State. The present study sought to profile the WBC counts among third trimester pregnant women, with a view to explore antepartum period, to suggest a possible explanation why infection is a leading causes of maternal death in this environment.

\section{Materials and methods}

The present study was approved by the ethical committee on human studies of the Sokoto State Specialist Hospital with reference number SHS/SUB/133. VOL1, (appendix V) and it satisfied the rules guiding human studies outlined by the Helsinki declaration. Every participant gave her informed written consent and that of her spouse (for the married participants) before being enrolled in the study. It was a longitudinal cohort study that engaged each participant three times at a regular interval to examine the changes in WBC profiles of pregnant women in their third trimester and compared the results with those of apparently healthy non-pregnant women sourced from the Sokoto metropolis.

Pregnant women in their early third trimester attending antenatal clinic at the Specialist Hospital Sokoto (SHS) and non-pregnant age match female controls sourced from the metropolis were recruited for the study. The data collection lasted about 6 months. Details of the study design, sampling techniques and procedural protocols are as explained in (Bamaiyi et al., 2013; Ibrahim, 2009; Sokoto state Government, 1995; Obidike, 2004).

Structured questionnaires were distributed to 207 women; 160 pregnant and 47 non-pregnant women, but 3 pregnant women were lost to follow up during the study. During the subject selection care was taken that only pregnant women who reside in the areas earmarked as the metropolis (Sokoto State Government, 1995) were included. Subjects were between 18 to 40 years old with singleton gestation based on sonographic findings obtained in their antenatal records and were in their third trimester and not suffering from any systemic illnesses. The control group was age- 
matched, non-gravid women who were nonsmokers and apparently healthy.

\section{Data collection}

Demographic data of subjects and controls were obtained from pretested structured questionnaires (appendixes III and IV). And subjects/controls were classified as eligible or ineligible using the screening tools administered (appendixes I and II). Each subject was contacted three times for the data collection procedures. Visits were after every second week.

During each contact measurements done were Blood pressure (BP), Weight (Kg), Height (m). And $2 \mathrm{mls}$ of free flowing venous blood samples were collected into EDTA bottles for the WBC analysis.

\section{Measurements}

Weight: This was taken at each visit and all the standard procedures were followed with a portable weighing scale (Camry, China, ISO 9001: 2008 certified by SGS, model: BR9012). The machine was standardized each weighing day using a known weight.

Height: This was measured once at the first contact with the subjects. A portable $(6 \mathrm{~kg})$ standiometer with a measuring range of 20 $250 \mathrm{~cm}$, calibrated in $\mathrm{mm}$, dimensions of $328 \mathrm{x}$ $21485 \times 574 \mathrm{~mm}$ was used and standard procedures were followed.

Body Mass Index (BMI): This was derived during every visit using the relation;

$$
\mathrm{BMI}=\text { weight }(\mathrm{kg}) / \text { height } \mathrm{x} \text { height }\left(\mathrm{m}^{2}\right)
$$

Haematological analysis: Syringes of $2 \mathrm{ml}$ single-use, and needles were used throughout the visits to collect venous blood using standard procedures and the blood transferred into $5 \mathrm{mls}$ tubes, anticoagulated with EDTA-2K and thoroughly mixed. These were transferred to the laboratory for analysis within 6hours.Automation method was used to determine the Total WBC (tWBC) and differentials. Full Automatic Blood Cell Counter, PCE - 210E, ver.5. 10 (Erma, Tokyo) was used for the analysis throughout the study.

\section{Statistical analysis}

Database was managed using IBM SPSS, version 23.0. Values were expressed as mean \pm SD. Tables and graphs were used to represent frequencies of variables. Student's t-test was used to compare sample means and Pearson's correlations and beta $(\beta)$ coefficients were utilized in determining relationship among variables. $P(\alpha)$ was set at $\leq$ 0.05 .

\section{Results}

Two hundred and four subjects stayed in the study to the completion, including 157 pregnant and 47 non-pregnant controls. The mean age of the pregnant group was $26.89 \pm 5.8$ years which was not statistically different from $28.02 \pm 6.8$ years, the mean for the non-pregnant control $(\mathrm{p}=0.265)$. As Nigeria is a multi-ethnic nation with economic, educational and development levels strikingly different from each other as one hovers from one group or region to the other, the participants in this study have been stratified for the purpose of comparisons. Table 1 shows the participants characteristics of the study groups. The distributions displayed the structure of the study environment, Sokoto state, Northwest Nigeria which is a predominantly Hausa and Muslim society.

\section{Variations in white blood cells}

Total WBC (tWBC) counts rose significantly by an

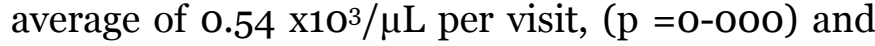
average weekly rise of $0.27 \times 10^{3} / \mu \mathrm{L}$ in the pregnant group. But, in the non-pregnant group a drop of $0.88 \times 10^{3} / \mu \mathrm{L}$ per visit was instead recorded, which was statistically significant ( $\mathrm{p}=0.003$ ), translating to $0.44 \times 10^{3} / \mu \mathrm{L}$ per week. The pregnant group generally had a significantly higher average tWBC count $\left(8.17 \pm 2.04 \mathrm{X}^{3} \mathrm{O}^{3} / \mu \mathrm{L}\right)$ than the non-pregnant control group with an average of $6.95 \pm$ $2.52 \times 10^{3} / \mu \mathrm{L}(\mathrm{p}=0.000)$. The lymphocyte count did not show much increment during subsequent visits $\left(0.02 \times 10^{3} / \mu \mathrm{L}, \mathrm{p}=0.419\right)$, and it was generally low $\left(0.89 \pm 0.44 \times 10^{3} / \mu \mathrm{L}\right)$ among the pregnant group compared to the non-pregnant group with an average of $1.51 \pm 1.21 \times 10^{3} / \mu \mathrm{L}$ $(p<0.05)$, decreasing by an average of $0.36 \times 10^{3} / \mu \mathrm{L}$ per visit $(\mathrm{p}=0.06)$. The monocytes count also increased with advancement in pregnancy age in 
the third trimester of pregnancy; increasing by about $0.05 \times 10^{3} / \mu \mathrm{L}$ with every subsequent visit. The monocyte count among the pregnant group, $\left(0.31 \pm 0.10 \times 10^{3} / \mu \mathrm{L}\right)$ was however significantly lower than the count of the matched non-pregnant control group $\left(0.43 \pm 0.29 \times 10^{3} / \mu \mathrm{L}\right)(\mathrm{p}=0.000)$. Like the monocytes, the granulocytes also increase in this trimester of pregnancy and was in addition significantly higher than the average counts recorded in the non-pregnant controls (6.98 \pm $1.9 \times 10^{3} / \mu \mathrm{L}$ Vs $\left.5.06 \pm 1.6 \times 10^{3} / \mu \mathrm{L}, \mathrm{p}=0.000\right)$. Other details about WBC and its components are as shown in Fig. 1.

Table 1. Participants' characteristics.

\begin{tabular}{llll}
\hline Variables & & $\begin{array}{l}\text { Pregnant women } \\
\text { number (percentage) }\end{array}$ & $\begin{array}{l}\text { Non-pregnant women } \\
\text { number (percentage) }\end{array}$ \\
\hline Tribes: & Hausa & $114(72.6)$ & $20(42.6)$ \\
& Yoruba & $20(12.7)$ & $7(14.9)$ \\
& Igbo & $8(5.1)$ & $10(21.3)$ \\
& Others & $15(9.6)$ & $10(21.3)$ \\
Religions: & & & \\
& Islam & $136(86.6)$ & $30(63.8)$ \\
& Christianity & $21(13.4)$ & $17(36.2)$ \\
Educational level: & & \\
& < Secondary school & $81(51.6)$ & $2(4.3)$ \\
& Secondary school & $51(32.5)$ & $3(6.4)$ \\
& $>$ Secondary school & $25(15.9)$ & $42(89.3)$ \\
Occupation $:$ & & & \\
& House wife/Student & $111(70.7)$ & $29(61.7)$ \\
& Business/Politician/Civil servant & $46(29.3)$ & $18(38.3)$ \\
Parity: & & & \\
& Nulliparous & $33(21.0)$ & $28(59.6)$ \\
& Parous & $124(79.0)$ & $19(40.4)$ \\
\hline
\end{tabular}

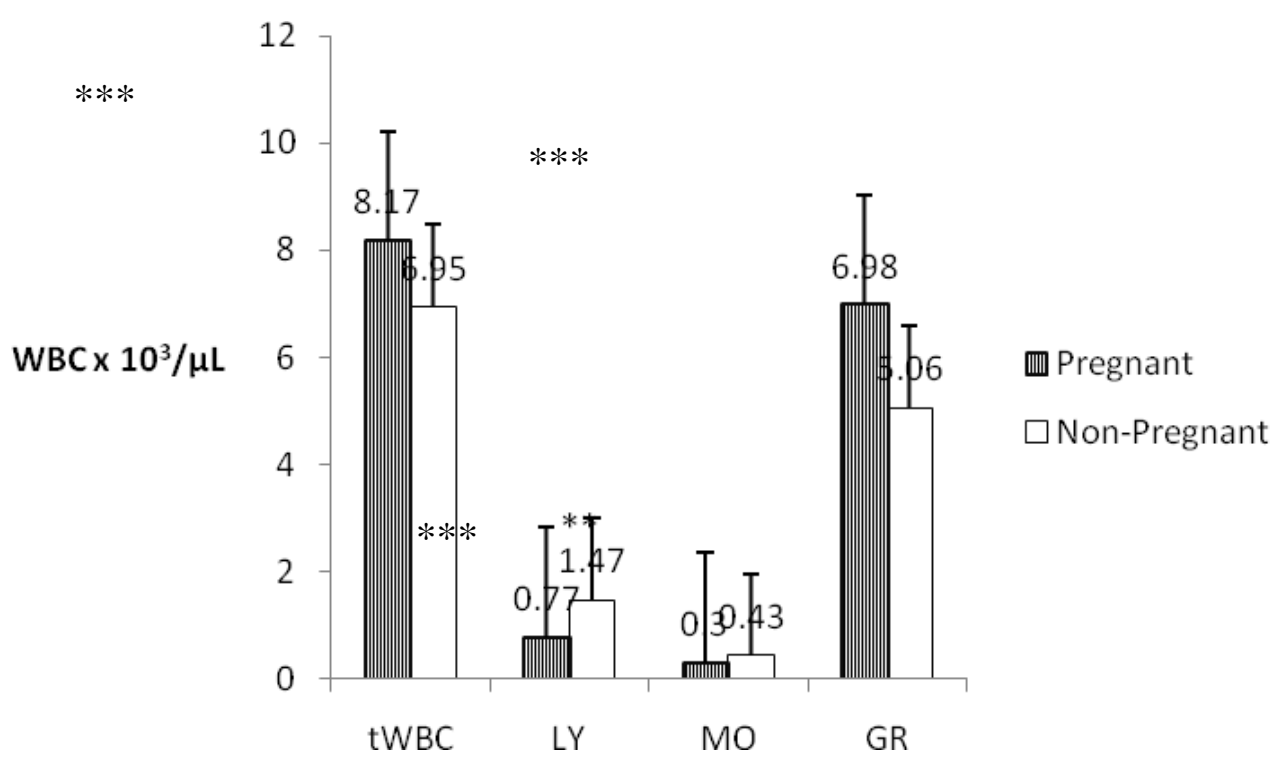

Fig. 1: WBC and its differentials in third trimester of pregnancy compared to the non-pregnant controls. N.B: tWBC (total WBC), LY (lymphocyte count), MO (monocyte count), GR (granulocyte count), * (statistically significance). 


\section{Weigh changes between groups}

It was also found that the average weight gain in the pregnant group per visit was about $0.99 \mathrm{~kg}$ giving a weight gain of about $0.5 \mathrm{~kg} /$ week. On the other hand, the non-pregnant control group showed about $0.26 \mathrm{~kg}$ increase per visit and about $0.13 \mathrm{~kg} /$ week. In both groups weight gain during the study period were not statistically significant $(\mathrm{p}=0.1819-0.9400)$.

Table 2. Relationship between WBC components and some variables of participants.

\begin{tabular}{|c|c|c|c|c|c|}
\hline \multirow{2}{*}{$\begin{array}{l}\text { Variables } \\
\text { tWBC Vs some variables of } \\
\text { participants: }\end{array}$} & \multicolumn{3}{|c|}{ Pregnant } & \multirow{2}{*}{$\begin{array}{l}\begin{array}{l}\text { Non- } \\
\text { pregnant }\end{array} \\
\text { p }\end{array}$} & \multirow[t]{2}{*}{$\begin{array}{l}\text { Level of } \\
\text { significance }\end{array}$} \\
\hline & $\mathbf{r}$ & $\mathbf{p}$ & $\mathbf{r}$ & & \\
\hline Education level & -0.113 & 0.206 & -0.409 & 0.077 & \\
\hline Occupation & 0.099 & 0.261 & 0.090 & 0.584 & \\
\hline Parity & -0.159 & 0.060 & -0.023 & 0.896 & \\
\hline$B M I$ & 0.060 & 0.465 & 0.119 & 0.446 & \\
\hline $\begin{array}{l}\text { LY Vs some variables of } \\
\text { participants: }\end{array}$ & $\mathbf{r}$ & p & $\mathbf{r}$ & $\mathbf{p}$ & \\
\hline Education level & 0.130 & 0.147 & -0.550 & 0.054 & \\
\hline Occupation & -0.003 & 0.976 & -0.108 & 0.483 & \\
\hline Parity & -0.012 & 0.892 & 0.041 & 0.801 & \\
\hline$B M I$ & -0.002 & 0.985 & 0.071 & 0.627 & \\
\hline $\begin{array}{l}\text { MO Vs some variables of } \\
\text { participants: }\end{array}$ & $\mathbf{r}$ & $\mathbf{p}$ & $\mathbf{r}$ & $\mathbf{p}$ & \\
\hline Education level & 0.074 & 0.414 & -0.298 & 0.058 & \\
\hline $\begin{array}{l}\text { Occupation } \\
\text { Parity }\end{array}$ & $\begin{array}{l}-0.051 \\
-0.010\end{array}$ & $\begin{array}{l}0.568 \\
0.903\end{array}$ & $\begin{array}{l}-0.077 \\
0.000\end{array}$ & $\begin{array}{l}0.657 \\
0.999\end{array}$ & \\
\hline$B M I$ & 0.002 & 0.980 & 0.169 & 0.312 & \\
\hline $\begin{array}{l}\text { GR Vs some variables of } \\
\text { participants: }\end{array}$ & $\mathbf{r}$ & $\mathbf{p}$ & $\mathbf{r}$ & $\mathbf{p}$ & \\
\hline Education level & -0.163 & 0.068 & -0.197 & 0.198 & \\
\hline Occupation & 0.115 & 0.188 & 0.265 & 0.126 & \\
\hline Parity & -0.170 & 0.043 & -0.077 & 0.670 & * \\
\hline$B M I$ & 0.065 & 0.423 & 0.121 & 0.458 & \\
\hline
\end{tabular}

N.B: tWBC (total WBC), LY (lymphocyte count), MO (monocyte count), GR (granulocyte count), * statistically significant.

\section{Relationships between WBC components and some variables of participants studied}

The results in Table 2 showed that during third trimester of pregnancy as well as among nonpregnant apparently healthy controls studied, level of education, ethnicity, occupation, parity or body mass index does not influence tWBC counts. Similarly, occupation, parity or body mass index does not influence lymphocytes counts in both groups studied. No association was noticed between the monocytes counts and any of the variables studied in either the pregnant or nonpregnant control groups. Moreover, no relationship again was observed between either BMI or MUAC and tWBC, lymphocytes or monocytes counts in both groups studied as demonstrated by the slopes of the relationships in figures $2 a-2 f$ and $3 a-3 f$.

\section{Discussion}

The major findings in the present study are; that tWBC is significantly high in the third trimester of pregnancy in Sokoto State, a predominantly Muslim and Hausa setting in Northwest Nigeria. That the lymphocytes and monocytes counts in this trimester were however significantly low compared to non-pregnant control group. Although both monocytes and lymphocytes counts mildly rises with advancement in pregnancy age in this trimester, the average count is significantly low when compared with the apparently healthy, nonpregnant controls. Furthermore, the granulocytes 
count does not only steadily increase in this trimester, it was significantly higher than the average recorded among the non-pregnant controls. However, the WBC and its components

(a)

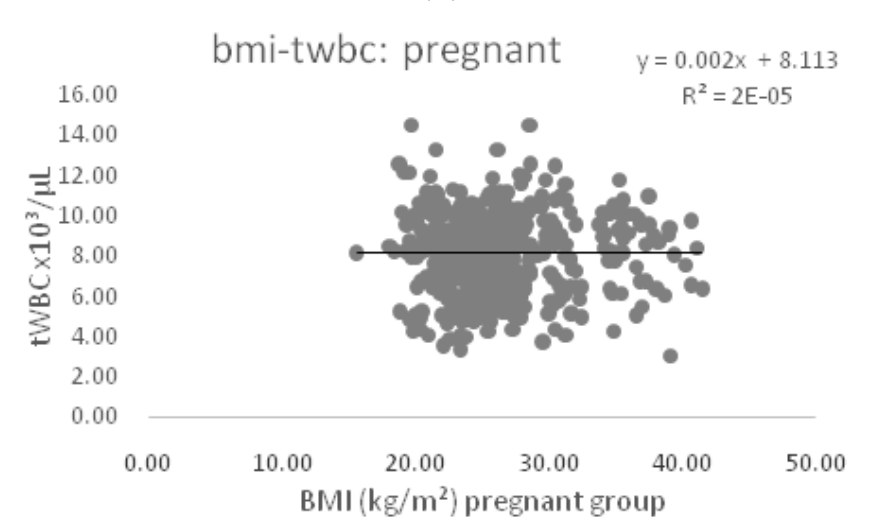

(c)

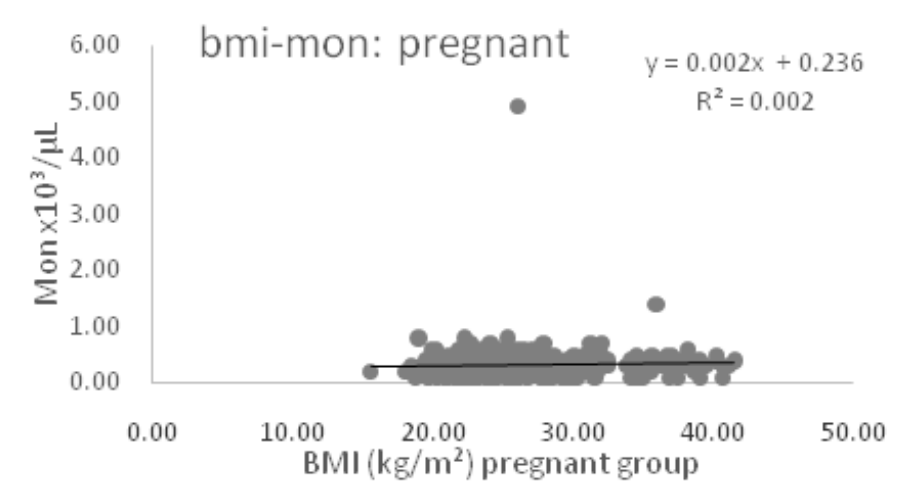

(e)

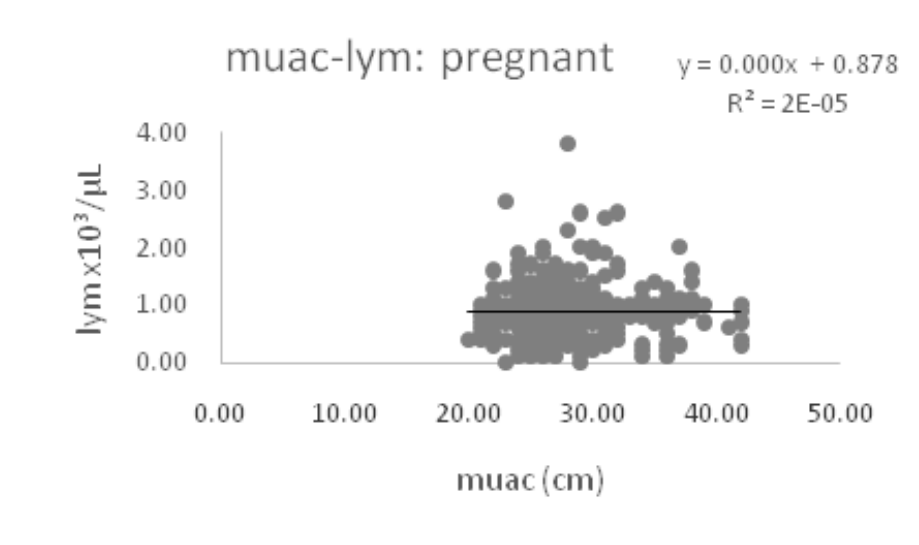

are apparently not influenced by the level of education, occupational status, parity, BMI or MUAC of either the pregnant or the non-pregnant control groups.

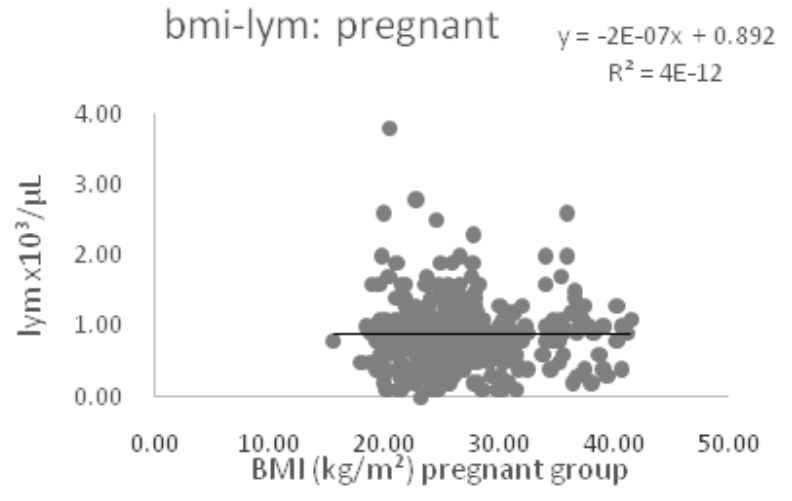

(d)

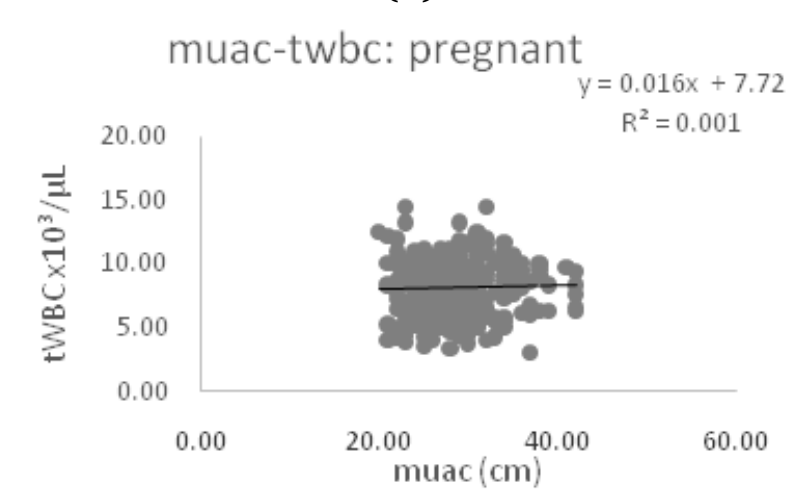

(f)

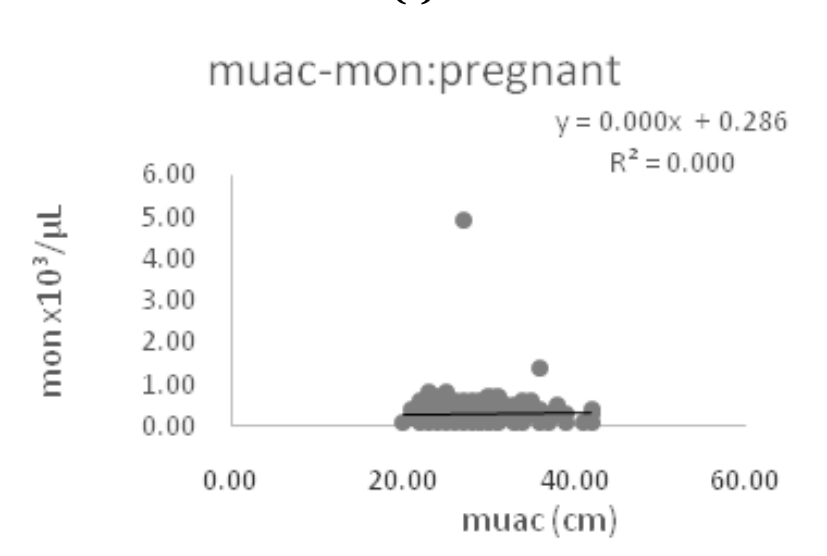

Fig. 2 (a-f): Relationships between BMI and MUAC with tWBC and its differentials in third trimester of pregnancy women. 
(a)

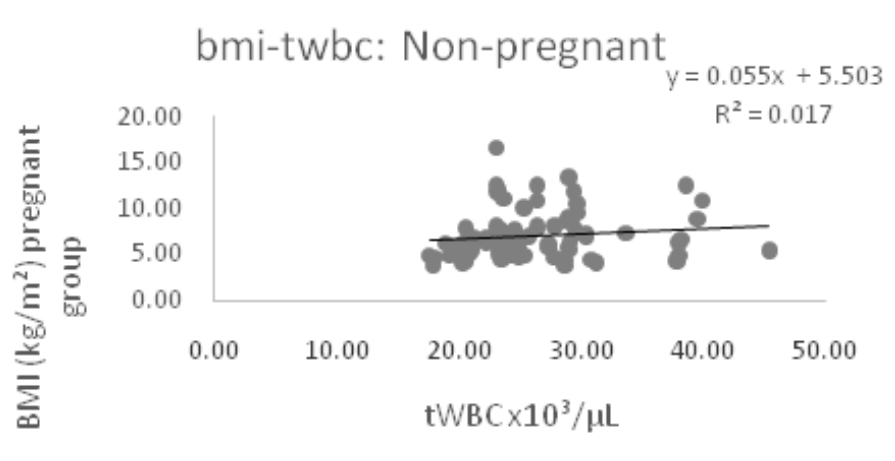

(c)

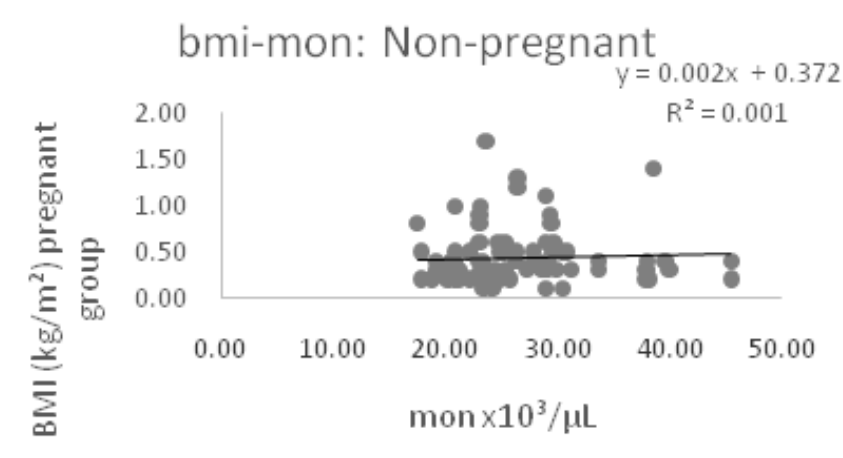

(e)

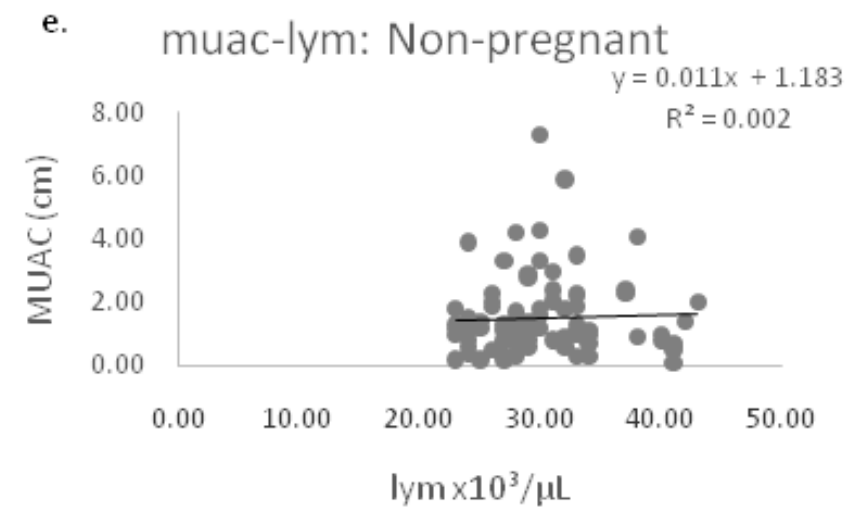

(b)

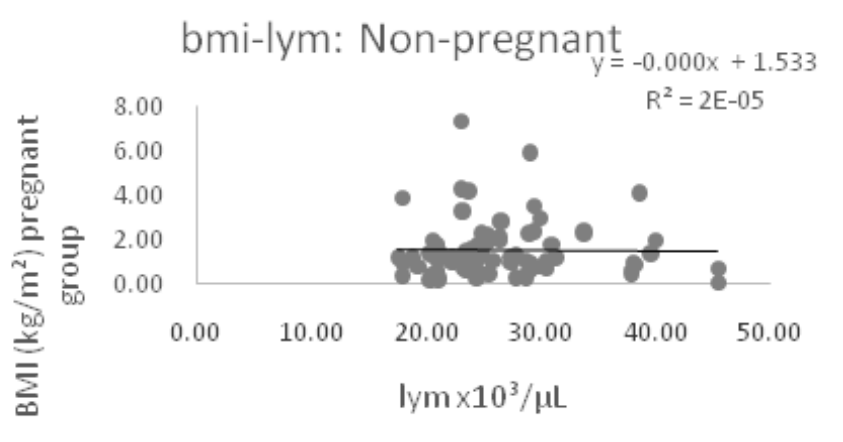

(d)

muac-twbc: Non-pregnant

$y=0.109 x+3.662$

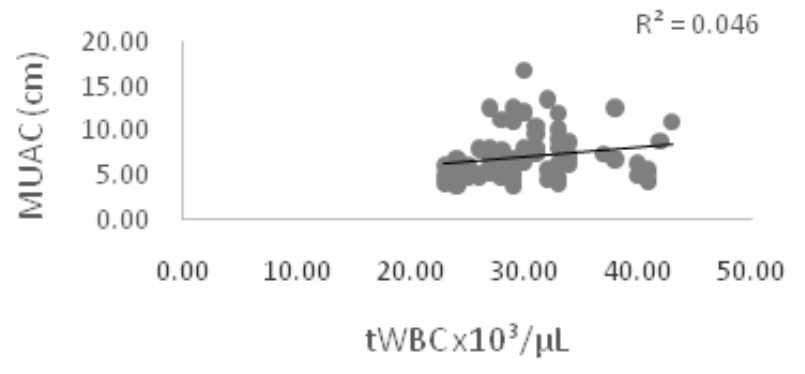

(f)

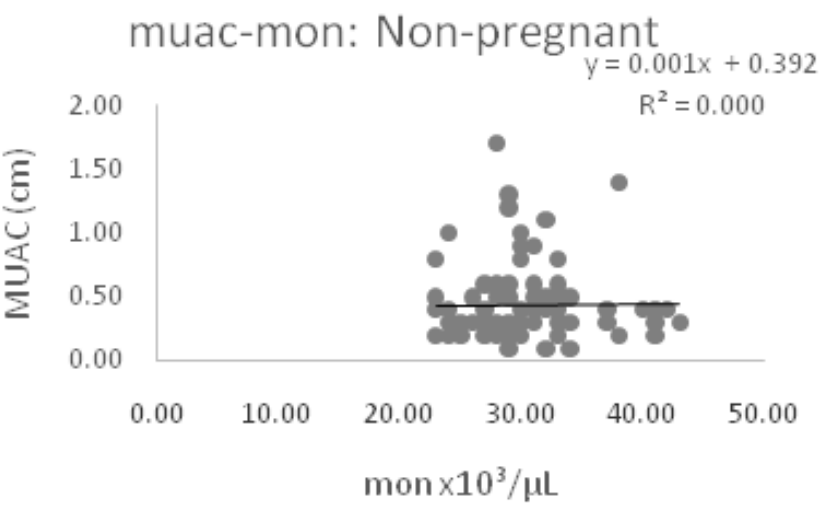

Fig. 3 (a-f): Relationships between BMI and MUAC with tWBC and its differentials among the nonpregnant controls.

Our results are in consonance with an earlier works by Onwukeme and Uguru (1990) in Jos, North-central Nigeria, Akingbola et al. (2006) in Ibadan, South-west Nigeria and in a review by Chandra et al. (2012), that tWBC count is significantly increased in the third trimester of pregnancy. This is however, in variance with other results (Dapper et al., 2006, Shen et al., 2010), that
WBC in pregnancy does not differ from a nonpregnancy state. Moreover, it was also reported that the increment in tWBC was all through the three trimesters of pregnancy (Akingbola et al., 2006, Onwukeme and Uguru, 1990). While we obtained an average tWBC in the third trimester to be $8.17 \pm 2.04 \times 10^{3} / \mu \mathrm{L}$, Obisesan and colleagues (1998) in Ibadan, Nigeria reported $5.765 \pm 1.753$ 


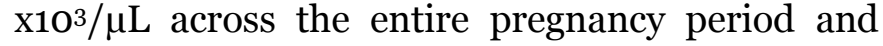
Onwukeme and Uguru (1990) reported $7.119 \times 10^{3} / \mu L$. Even though our study consistently collected blood samples in the morning to avoid circadian variations of WBC among pregnant women in their third trimester of pregnancy, the tWBC $\left(8.17 \pm 2.04 \times 10^{3} / \mu \mathrm{L}\right)$ is on the higher side when compared to the values across Nigeria (5.77 $\left.-7.36 \times 10^{3} / \mu \mathrm{L}\right)$, including the Northern average $\left(7.12 \pm 2.36 \times 10^{3} / \mu \mathrm{L}\right)$ (Pughikumo et al., 2015, Obisesan et al., 1998, Onwukeme and Uguru, 1990). Indeed, the higher tWBC in the present study confirms the value recently reported by Musa and colleagues (2016) among pregnant women undergoing antenatal care in a sister tertiary health institution in Sokoto. Whether the higher leucocytosis in the third trimester of pregnancy in our results was due to physiological leucocytosis of pregnancy (Wang et al., 2016; Malikarjun et al., 2018), even when a similar northern Nigerian average is lower could still be explained in possible differences in the stress (pregnancy and otherwise) which these groups of pregnant women undergo and for our study which focused only on the third trimester during which stress is expected to be more profound requires further research. Given that these study groups were from the different geo-political zones of Nigeria with their different culture and women lifestyles, and stress levels during pregnancy may be a possible explanation as pointed out to be a major factor in leukocytosis of pregnancy (Chandra et al., 2012). Whether these explain the higher values in our study may require further investigations where confounders such as identified stressors in pregnancy can be accounted for.

The lymphocyte and monocytes counts in the present study were also significantly low compared to the non-pregnant control. Although, the study by Ichipi-Ifukor et al. (2013) reported lymphocyte count to be higher during pregnancy compared to non-pregnant control, the report by Chandra and colleagues (2012) and Dapper et al (2006) corroborate our finding that lymphocyte count increases in the third trimester, but the average is still low compared to the non-pregnant controls. Furthermore, while monocytes counts are expected to be on the increase (Ramsay, 2010), in the present study the count was significantly low compared to both the control group and values in studies carried out elsewhere. This may be explained by a drastic fall in the counts during the first and second trimesters reported by Chandra et al. (2012). Moreover, the lymphocyte count in our pregnant subjects was found to be lower than those reported elsewhere (Dapper and Didia, 2006; Ichipi-Ifukor et al., 2013; Obeagu et al., 2014). Whether this may be explaining why infection among others is a leading risk factor for the high maternal deaths in our setting will require further research. Importantly, adequate normal lymphocyte counts are essential to produce humoral and cell-mediated immunities as well as priming pathogens for phagocytosis by the neutrophils and monocytes. And even if these latter two were raised, they may not be able to function well, as adequate normal lymphocytes counts are required to complement their proper functioning. Besides, the high counts of granulocytes (neutrophils) observed may be attributed to failure of normal apoptotic processes (Chandra et al. 2012). Furthermore, pregnancy serum itself is reported to subject the raised granulocytes count to a suppressive milieu characterized by oxidative changes seen in their cytoplasm (Chandra et al., 2012).

\section{Study limitations}

The relatively small sample size and short timeframe of the present study forecloses assessing pregnancy outcomes of the participants and therefore doesn't allow for drawing of conclusions. Similarly, further investigations were not carried out to confirm the presence of infections in the pregnant group, therefore the WBC parameters observed in the present study might be a result of a plethora of reasons that can occasion the rise. Moreover, only third trimester pregnant women were considered and a large majority of the participants were from one ethnic group, Hausa this might have introduced ethnic biasness.

\section{Conclusion}

The significantly reduced level of lymphocytes and monocytes with raised level of WBC (granulocytes) observed towards the end of pregnancy in the present study when compared to their nonpregnant age-matched counterparts and other contemporary values, may explain the vulnerability of the pregnant women in this environment, especially peripartum to infections and hence its 
contribution to high prevalence of morbidity and mortality (Mojekwu and Ibekwe, 2012, Audu and Ekele, 2002). Health education on factors that enhance health in pregnancy such as effective infection prevention and control, adequate nutrition and healthy lifestyle should be emphasised during antenatal services to the pregnant mothers. We recommend that health policy makers develop policies aimed at promoting maternal and child health with particular emphasis for proper antenatal care and safe delivery.

\section{Conflict of interest statement}

Authors declare that they have no conflict of interest.

\section{References}

Ahmed, W. M. M., Khalid, A. \& Musa, O. A. 2018. Effect of pregnancy on packed cell volume and total white blood cells count among Sudanese pregnant women attending antenatal care at Ribat University Hospital (Khartoum state). International Journal of Reproduction, Contraception, Obstetrics and Gynecology, 7, 371.

Akingbola, T. S., Adewole, I. F., Adesina, O. A., Afolabi, K. A., Fehintola, F. A., Bamgboye, E. A., Aken'ova, Y. A., Shokunbi, W. A., Anwo, J. A. \& Nwegbu, M. M. 2006. Haematological profile of healthy pregnant women in Ibadan, south-western Nigeria. J Obstet Gynaecol, 26, 763-9.

Akinlaja, O. 2016. Hematological Changes in Pregnancy - The Preparation for Intrapartum Blood Loss. Obstetrics \& Gynecology International Journal, 4.

Audu, L. R. \& Ekele, B. A. 2002. A ten year review of maternal mortality in Sokoto, northern Nigeria. West Afr J Med, 21, 74-6.

Bamaiyi, A. J., Adelaiye, A. B. \& Igbokwe, V. U. 2013. Relationship between anthropometric and haematological parameters among third trimester pregnant women in Sokoto State, Northwest Nigeria. Niger J Physiol Sci., 28, 211-9.

Bamaiyi, A. J., Adelaiye, A. B. \& Igbokwe, V. U. 2015. Effects of Anthropometric and Parity Factors on Blood Pressure (BP) Pattern of Third Trimester Pregnant Women in Sokoto, North-West, Nigeria. Gynecology \& Obstetrics,
05.

Chandra, S., Tripathi, A., Mishra, S., Amzarul, M. \& Vaish, A. 2012. Physiological Changes in Hematological Parameters During Pregnancy.

Ciliberto, C. F. \& Gertie, F. M. 1998. Physiological Changes Associated With Pregnancy, Dept of Anaesthesiology, Albert Eistein College of Medicine, New York, USA. Physiology, 9, 1-3.

Dapper, D. V. \& Didia, B. C. 2006. Haemorheological parameters of umbilical cord blood of Nigerian newborns:correlations with maternal parameters. West Afr $J$ Med., 25, 226-30.

Dapper, D. V., Ibe, C. J. \& Nwauche, C. A. 2006. Haematological values in pregnant women in Port Harcourt, Nigeria. Niger J Med, 15, 23740.

Duru C.B., Nnbue. C. C., Nwakwe. K. A., Diwe. K. C., Agunwa. C.C., Achigbu. K. I., Iwu. C. A., Merenu. I. A., 2016. Prevalencd and pattern of herbal medicine use in opregnancy among women attending cloinics in a tertiary hospital in Imo state, South east Nigeria. Int.J. Curr. Res.Biosci. plant Biol. 3(2), 5-14 doi:http://dx.doi.org/10.20546/ijcrbp.2016.30 2.002

FIGO 2013. Maternal deaths down in Sokoto State. Gynaecology and Women's Health.

Gebreweld, A., Bekele, D. \& Tsegaye, A. 2018. Hematological profile of pregnant women at St. Paul's Hospital Millennium Medical College, Addis Ababa, Ethiopia. BMC Hematology, 18, 15.

Ibrahim, T. 2009. Sample Size Determination; Research Methodology and Dissertation Writing for Health and Allied Health Professionals. Published by Cress Global Link Limited, Abuja. ISBN: 978-978-906-838-8. , Ch5:, 70-75.

Ichipi-Ifukor, P. C., Jacobs, J., Ichipi-Ifukor, R. N. \& Ewrhe, O. L. 2013. Changes in Haematological Indices in Normal Pregnancy. Physiology Journal, 2013, 1-4.

Kaur, S., Khan, S. \& Nigam, A. 2014. Hematological profile and pregnancy: a review. International Journal of Advances in Medicine, $1,1$.

Malikarjun Rao. V., B.M. Shanker Venkatesh and Rajeshwer Rao, S. 2018. Asymptomatic Bacteriuria in pregnant women-study at a tertiary maternitycare hospital in Hyderabad, 
india. Int.J. Curr. Microbiol. App. Sci. 7(05): 1133-1142.

Mojekwu, J. N. \& Ibekwe, U. 2012. Maternal Mortality in Nigeria: Examination of Intervention Methods. International Journal of Humanities and Social Science Vol. 2 No. 20

Mor, G. \& Cardenas, I. 2010. The Immune System in Pregnancy: A Unique Complexity. American Journal of Reproductive Immunology, 63, 425-433.

Musa, Abubakar U \& Ndakotsu, Muhammad A \& Abubakar Panti, Abubakar \& Shehu, Constance E \& Kaoje, Aminu U. 2016. Haematological variables of healthy pregnant women in Sokoto, North-western Nigeria. Sub-Saharan African Journal of Medicine. 3. 194.

Obeagu, E. I., Obarezi, T. N., Eze, O. B. L. \& Emelike, C. U. 2014. Haematological profile of pregnant women in Umahia, Abia State, Nigeria. Int. J. Microbiol. App. Sci, 3, 713-718.

Obidike, E. K. 2004. Measurements; Essential of Clinical Methods in Paediatrics. Published by Institute for Development Studies, University of Nigeria, Enugu Campus, Enugu-Nigeria, Ch14, p112.

Obisesan, K. A., Adeyemo, A. A. \& Okunade, M. A. 1998. Haematological values in pregnancy in Ibadan, Nigeria. Afr J Med Med Sci, 27, 9-11.

Onwukeme, K. E. \& Uguru, V. E. 1990. Haematological values in pregnancy in Jos. West Afr J Med, 9, 70-5.

Pattanathaiyanon, P., Phaloprakarn, C. \& Tangjitgamol, S. 2014. Comparison of gestational diabetes mellitus rates in women with increased and normal white blood cell counts in early pregnancy. $J$ Obstet Gynaecol Res, 40, 976-82.

Pughikumo, O. C., Pughikumo, D. T. \& Omunakwe, H. E. 2015. White Blood Cell Counts In Pregnant Women in Port Harcourt, Nigeria IOSR Journal of Dental and Medical Sciences (IOSR-JDMS), 14, PP 01-03

Ramsay, M. 2010. Normal Haematological Changes During Pregnancy and Puerperium. The Obstetric Haematology Manual., Cambribge University Press, ; p3 - 12.

Serrano, B., Almeria, S., Garcia-Ispierto, I., Yaniz, J. L., Abdelfattah-Hassan, A. \& Lopez-Gatius, F. 2011. Peripheral white blood cell counts throughout pregnancy in non-aborting Neospora caninum-seronegative and seropositive high-producing dairy cows in a Holstein Friesian herd. Res Vet Sci, 90, 457-62.

Shen, C., Jiang, Y. M., Shi, H., Liu, J. H., Zhou, W. J., Dai, Q. K. \& Yang, H. 2010. A prospective, sequential and longitudinal study of haematological profile during normal pregnancy in Chinese women. $J$ Obstet Gynaecol, 30, 357-61.

Sokoto State Government, N. 1995. Establishing and Empowering Sokoto State Urban and Regional Planning Board (SSURPB).To Control Development in All the Local Governments in the State. Edict 7.

Wang, H., Sun, J. L., Zhang, Z. L. \& Pei, H. H. 2016. Pregnancy complicated with agranulocytosis. Medicine (Baltimore), 95, e5717.

\section{How to cite this article:}

Bamaiyi, A. J., Ladan, K. A., 2019. White blood cell profile during third trimester of pregnancy in Sokoto, Nigeria. Int. J. Curr. Res. Biosci. Plant Biol. 6(10), 1-10.

doi: https://doi.org/10.20546/ijcrbp.2019.610.001 